\title{
The Smuggling of Cash and (Or) Monetary Instruments: Is the Sentence Final and Binding?
}

\author{
Stanislav I. Golubev*1,Natalia E.Panfilova ${ }^{2}$,Nikolay N.Rybushkin ${ }^{3}$ \\ ${ }^{1}$ Kazan Federal University, Law Faculty, Criminal Law Department; \\ ${ }^{2,3}$ Kazan Federal University, Faculty of Law \\ Email: tasikitten1@ rambler.ru ; Contact +7 (905) -313-12-48
}

\section{Received: $21^{\text {st }}$ October 2017 Accepted: $16^{\text {th }}$ November 2017, Published: $31^{\text {st }}$ December 2017}

\begin{abstract}
Being a part of the internal and foreign policy of a state, the customs policy is formed under the influence of the customs affairs, their place and role in solving the actual problems of foreign trade regulation, embraces the strategy of domestic and international events related to trade relations. A well-thought-out and purposeful customs policy contributes to the dynamic development of a state, while miscalculations in this sphere not only have an adverse effect in the economy, but also contribute to the growth of social contradictions, and may even lead to aggravation of international relations.

Smuggling is inextricably linked with the development of customs, the economy of the country, domestic and foreign trade. It develops in any social and economic conditions both in the case with the liberalization of customs tariffs, and when they become tougher. In the first case, the weakening of control over foreign trade activity contributes to the expansion of illegal import and export of goods, in the second case extremely burdensome custom duties make foreign goods uncompetitive. In both situations, measures to regularize customs fees and duties, their systemic and understandability, and the development of the system of customs and law enforcement bodies have certain effectiveness. Particular attention should be given to criminal law measures as the most repressive tool in countering smuggling. To this end, problems and effectiveness of the application of such criminal law measure as confiscation are revealed, based on the analysis of available judicial practice (the total number of materials studied is 140).
\end{abstract}

Keywords: Smuggling, Money Smuggling, Smuggling Penalization, Confiscation

\section{Introduction}

Smuggling refers to one of the oldest types of crimes and, from the etymological point of view, designates the secret transportation or transfer of goods and valuables across a state border with their concealment from customs control or secretly carried or transported across the state border.

The Soviet period was characterized by the nationalization of foreign trade activity, which was under the control of the state and was carried out on behalf of the Russian Republic by specially authorized bodies. Monetary means, including foreign currency, were also limited in circulation and were allowed to be exported only with special permission [1].

The disintegration of the USSR in 1991 led to a crisis in the field of foreign trade regulation, which led to the adoption of regulatory documents that established customs and administrative boundaries with the former Soviet republics. This initiated the formation of the customs infrastructure at the country's border and became a prerequisite for control the movement of goods across borders and the creation of a system to counter smuggling.

These processes were accompanied by a change in administrative and criminal legislation: a uniform rule that regulated the occurrence of criminal liability for smuggling (article 78 of the Criminal Code of the RSFSR) was reproduced in article 188 of the Criminal Code of the Russian Federation, and then the division of components of crime was made, depending on the object and the subject of criminal encroachment.

The direct object of such contraband was the most diverse social relations: in the sphere of economy, in the financial sphere, in the sphere of public security, and in the public order.

With the adoption of the Criminal Code of the Russian Federation, smuggling of currency was not considered as a single crime having an independent enshrining in one of the norms of the Special Part, but was included in the subject of Part 1, Article 188 of the Criminal Code of the Russian Federation along with other subjects.

In accordance with the changes made in December 2011, the legislator completely abandoned the notion of economic contraband. The new rules contained a rather large list of items restricted and banned in free circulation on the territory of the Russian Federation, but public relations securing the economic and financial sphere ceased to be protected. There was no such thing as money and currency in the dispositions of the articles.

Federal Law dated June 28, 2013 No. 134-FZ of the Criminal Code of the Russian Federation was amended by Article 200.1 providing for liability for the smuggling of cash and (or) monetary instruments. The development and adoption of the law are due to the need to implement the recommendations of the FATF into national legislation.

In particular, the recommendations indicate that countries should have measures in place to identify the physical cross-border movement of cash and negotiable 
instruments to bearer, including through a declaration system and / or an information system.

Countries should ensure that their law enforcement agencies have the legal authority to suspend or restrict the movement of cash or negotiable instruments to bearer suspected of financing terrorism or money laundering, or predicate offenses, or that are not legally declared, or which is represented by inaccurate information.

It is emphasized that countries must ensure application of effective, proportionate and deterrent sanctions to the persons who perform false declaration or represent false information. In cases where cash or negotiable instruments to bearer are related to the financing of terrorism, money laundering or predicate offenses, countries should also take measures, including legislative ones, which would ensure the confiscation of such cash or instruments [2].

The issues of counteracting to smuggling are currently the subject of scientific analysis by both foreign [3-8] and domestic scientists, but they, as a rule, do not turn to the study of law enforcement problems and the punishability of smuggling [9-13]. The exception, perhaps, is only the work of N. Kolokolov [14].

\section{Materials and Methods}

The empirical basis for the study was the statistical data received from the Main Information and Analysis Center of the Ministry of the Internal Affairs of Russia (Fond 491) and the Judicial Department attached to the Supreme Court of the Russian Federation. In 2016, the Court Department at the Supreme Court of the Russian Federation published data only for the first half of the year. Also, verdicts and court decisions posted in legal reference system "Consultant Plus" and on the site https://rospravosudie.com/ were analyzed. The total number of materials studied is 140 .

According to statistics, in 2014, 58 crimes under article 200.1 of the Criminal Code of the Russian Federation were registered, 76 persons were convicted, in 3 cases confiscation of property was applied, in 2015 - 98, 35 and 9, in 2016 - 78, 13 and 4, respectively.

\section{Results and Discussion}

The study of sentences and other judicial decisions shows that, in general, there are no difficulties in labeling process; the main reason for appealing against the sentence is the unjustified application of the confiscation of property. However, no more than $5 \%$ of all incoming complaints is satisfied.

According to Part 1,Article 104.1 of the Criminal Code of the Russian Federation, confiscation of property, i.e. compulsory gratuitous seizure and transfer to the ownership of the state on the basis of a conviction, is applied to money, valuables and other property received as a result of the commission of crimes or subject to illegal movement across the customs border of the Customs Union within the Eurasian Economic Community or across the State border of the Russian Federation with Customs Union Member States within the framework of the Eurasian Economic Community, and any income from this property, with the exception of property and income from it, subject to return to rightful owner.

Difficulties are caused by the interpretation of the statutory exception, namely, the return of property (money) to the rightful owner. Judicial practice abounds with various arguments of convicts in favor of returning money to the rightful owner, since they are, for example:

- belong to the mother of the convict and were intended to purchase by her real estate (or other property) in a foreign country;

- belong to another person, as they were obtained from the sale of his/her property and the court actually punishes an innocent person who was not involved in the criminal case;

- taken from another person on loan, which is confirmed by receipt;

- belong to a different person, which is confirmed by the testimony of the latter.

Thus, this group of arguments is reduced to the presence of an established owner of money or that person in whose interests the convicted person acted. As a rule, the court does not take into account these arguments, pointing out that the reference to belonging the money confiscated from the convicted person to other persons does not in itself give unconditional grounds for transferring to their owners the funds which have been illegally transferred across the customs border.

The courts also point out that the legal owner of the funds is not deprived of the right to independently apply to the court as a separate civil procedure and to demand compensation from the guilty party.

There are however other precedents when the court referring to Article 307 of the Code of Criminal Procedure, which establishes that the descriptive and motivational part of the judgment of conviction must contain the motives for resolving all issues relating to the appointment of punishment, the evidence on which the court's conclusions on the defendant are based, and the reasons why the court rejected other evidence, abolished the decisions of lower courts and sent them for a new examination.

In particular, it was stated that the court of first instance did not check and did not give a proper assessment of the convict's arguments that the money withdrawn from him belongs to another person.

In another decision of the appellate court it was stated that the requirements of Part 4, Article 7 of the Criminal Procedure Code of the Russian Federation, which provides that court orders issued in accordance with articles 396-397, the Code of Criminal Procedure of the Russian Federation, must be lawful, substantiated and motivated, based on the materials of the case examined by the first-instance court, when the decision was taken, were not fully implemented. In particular, according to the protocol of the court 
session, a copy of the receipt from the convicted person of reception of funds from their legal owner and written explanations of the latter by the court of first instance in the criminal case file has not been examined and they have not been properly assessed. This led to the cancellation of the decision.

Appeal against the decisions of the courts of first instance on the grounds that the money was not obtained by criminal means, legally belong to the convicted person and, for example, are his/her personal savings, are also practically not accepted as grounds for cancellation of the judicial decision.

Thus, it is stated that the cash funds for which the criminal actions of the convicted person were directed, are the subject of illegal movement across the customs border of the Customs Union within the framework of the Eurasian Economic Community, regardless of whether the convicted person was a bona fide or unscrupulous owner of these funds, in accordance with the requirements of Section 2, Part 1, Article 81, the Code of Criminal Procedure of the Russian Federation. At the same time, it is impossible to speak about the unambiguousness of approaches in judicial practice. The review of the appellate practice in the criminal cases of the Court of the Jewish Autonomous Region cites the sentence of the Leninsky District Court of the Jewish Autonomous Region dated 05.05.2015 regarding a certain V.S. convicted of. Part 1, Article 200.1, of the Criminal Code to a fine of 20,000 rubles which was changed in part of the decision on material evidence.

The court decided to confiscate funds in the income of the Russian Federation, while a part of the money amount was decided to return the citizen of the People's Republic of China, a certain Ch.L.

Shaping the future of physical evidence, money withdrawn from V.S., the court made the wrong decision, returning only a part of these funds to their rightful owner, Ch. L., and the rest of the amount decided to draw into the income of the Russian Federation.

It follows from the materials of the case that on 23.12.2014, Ch.L. has received a certain sum of money from the bank of the People's Republic of China and gave it to V.S. to transfer them to her husband Ch.V. who was engaged in economic activities on the territory of Russia. At customs examination, this amount was withdrawn from V.S. as it was not declared.

The Court of First Instance returned only a part of the withdrawn amount in accordance with the incorrect and unmotivated decision., recognizing for her the right of legal possession only in part of this money.

According to the provisions of Article 104.1 of the Criminal Code of the Russian Federation, confiscation should be applied to the money and other property received as a result of crimes, guilt in the commission of which is established in accordance with the procedure provided by law.
The transportation of undeclared property across the border entails criminal liability for such actions for the guilty person. However, this responsibility does not mean unconditional confiscation of the transported property through the compulsory and uncompensated withdrawal of it from circulation into state ownership. In order to confiscate property, in particular money, in accordance with Article 104.1 of the Criminal Code of the Russian Federation it is necessary to prove that these funds were obtained as a result of the commission of a crime or were intended to finance criminal organizations, as expressly provided for in Section 8, Part 1, 73 of the Code of Criminal Procedure.

Examples of the return of funds to the rightful owner are still quite rare. One of those is the decision of the Sverdlovsk Regional Court. The sentence of the court has found a certain Kh. guilty of illegally moving cash across the customs border of the Customs Union within the framework of the Eurasian Economic Community in a large amount; it was decided to return cash in the amount of 2,965,000 US dollars to the company M. as a legal owner, and to confiscate cash in the amount of 3,700 dirhams UAE and 900 dollars belonging to $\mathrm{Kh}$. Appeal decision of the Sverdlovsk Regional Court has cancelled the sentence regarding the material evidence, namely, cash in the amount of US 2,6565,900 dollars and 3,700 dirhams of the UAE; it was decided to confiscate and transfer the above mentioned funds to the state's income, with the exception of a sum equivalent to 10,000 dollars returning it to the convicted person $\mathrm{Kh}$.

By decision of the Presidium of the Sverdlovsk Regional Court of August 19, 2015, the appeal decision of the Sverdlovsk Regional Court of September 25, 2014 regarding the issue of confiscation of funds in the amount of 2,965,900 dollars and 3,700 dirhams of the UAE was canceled, the case file in this part was sent for a new trial to the appellate instance.

\section{Summary}

Confiscation is now spreading upon resolutions of criminal cases under article 200.1 of the Criminal Code of the Russian Federation, but cases of return of funds to their legal owner according to a judicial decision are quite rare, which is not the least due to the lack of a uniform interpretation of the Criminal Code provisions and the Code of Criminal Procedure of the Russian Federation.

We believe that the activities of the courts must be clear and transparent, the procedural legislation should contain a perfect mechanism for correcting judicial errors, and the introduction of the notion of "legal owner of the subject of smuggling" should receive a clear, unambiguous consolidation in the law or in the Supreme Court of the Russian Federation. 


\section{Conclusion}

One of the reasons for establishing responsibility for the smuggling of cash and (or) other monetary instruments was the need to implement the FATF recommendations into national legislation, including the need to ensure the use of effective, proportionate and deterrent sanctions against persons who doubtfully declare cash and cash instruments to bearer. The purpose of criminalizing this act was also to increase the effectiveness of the fight against money laundering, including by controlling a cross-border movement of cash that is often used to finance terrorism and for other purposes that undermine the economic and sociopolitical foundations of a state.

It seems that the main way to counteract the illegal circulation of funds is the use of criminal punishment, as well as other measures such as confiscation. At present, it is the application of confiscation in the judicial practice that is the main reason for appealing against sentences passed under Article 200.1 of the Criminal Code of the Russian Federation, what requires the attention of law enforcement agencies.

\section{Acknowledgements}

The work is carried out according to the Russian Government Program of Competitive Growth of Kazan Federal University.

\section{References}

1.Markovsky M.S. Development and specificity of the Soviet legislation establishing the order of currency transfer across the state border // History of state and law. - 2015. - No. 21.-P. 39-43

2.Recommendations of the FATF. International standards on combating money laundering, financing of terrorism and financing the proliferation of weapons of mass destruction. - M., 2012. - P. 34.

3.Toktas Sule, Selimoglu Hande. Smuggling and Trafficking in Turkey: An Analysis of EU-Turkey Cooperation in Combating Transnational Organized Crime // Journal of Balkan \& Near Eastern Studies. 2012. - Vol. 14. - Issue 1. - p. 135-150.

4. Alldridge P. Smuggling, Confiscation and Forfeiture // The Modern Law Review. - 2002. - Vol. 65(5). - p. 781-791

5. Swagato S. The illicit economy of power: smuggling, trafficking and the securitization of the Indo-Bangladesh borderland // Dialectical Anthropology. - 2017. - Vol. 41. - Issue 2. - p. 185199.

6. Sang Kook Lee. Behind the Scenes: Smuggling in the Thailand- Myanmar Borderland // Pacific Affairs. 2015. - Vol. 88. - Issue 4. - p. 767-790.

7. Buehn A.; Farzanegan Mohammad Reza. Smuggling around the world: evidence from a structural equation model // Applied Economics. - 2012. - Vol. 44. - Issue 23. - p. 3047-3064.

8. Wajid Zainab; Aziz Babar; Iqbal Zahid. Smuggling around the World: An Empirical Investigation of
Causes and Indicators // Forman Journal of Economic Studies. -2014. -Vol. 10. - p. 105-133.

9.Kuznetsov A.P. Smuggling of cash and (or) monetary instruments (article200.1 of the Criminal Code): criminal law regulation and qualification issues / / Russian investigator. - 2015.-No. 2. - P. 29-33.

10.Urda M. Questions of qualification of smuggling of money and (or) monetary instruments // Criminal law. 2014. - No. 3. - P. 78-82.

11.Markovsky M.S. On the issue of the smuggling object of cash and (or) monetary instruments / / Bulletin of the Moscow University of the Ministry of Internal Affairs of Russia. - 2015. - No. 8. Pp. 124-128. 12.Prihodko N.Yu. Controversial issues in the object of contraband and possible ways to solve them // Customs. - 2016. - № 4. - P. 25-28.

13.Kolokolov N. Smuggling: was the confiscation of property reanimated? // "Ezh-LAWYER". 2015. No. 47. 